\title{
Waqf Financial Tecnology in Startup Capital
}

\author{
Uswatun Hasanah ${ }^{1}$, Darma Pranata ${ }^{2}$, \\ \{uswatunchasanah119@gmail.com ${ }^{1}$, pranatadarma2@gmail.com ${ }^{2}$ \}
}

${ }^{1,2}$ Graduate School, State Institute For Islamic Studies Of Metro, Ki Hajar Dewantara Street 15 A Iringmulyo Kota Metro, Lampung, Indonesia

\begin{abstract}
If managed properly, productive waqf can be used as a new strategy to alleviate poverty, create prosperity, and support economic stability. In Indonesia, productive waqf has been approved by national law and the Indonesian Council of Ulama (MUI). This is a positive opportunity to develop the better economy and education. However, there is still lack of understanding on the importance of productive endowments for development. as a consequence, there should be a specific stimulus so that that the management of waqf can be developed productively and supported by financial technology.
\end{abstract}

Keywords: productive waqf, startup, financial technology

\section{Introduction}

Fintech comes from the term "financial technology". According to The National Digital Research Center (NDRC), in Dublin, Ireland, fintech is "innovation infinancial services" or "innovation in fintech financial services" which is an innovation in the financial sector that gets a touch of modern technology. Financial transactions through fintech include payments, investments, money lending, transfers, financial plans and comparison of financial products. Currently there are 142 companies engaged in fintech.[1]

There are a number of fintech in Indonesia, such as payment startup, lending, financial planning (personal finance), retail investment, financing (crowdfunding), remittances, and financial research. Fintech is recognized as one of the most important innovations in the financial industry and is growing rapidly, driven by economic equity, favorable regulation, and information technology.

Digital-based financial services that are currently developing in Indonesia are, among others, payment channel systems, digital banking, online digital insurance, Peer to Peer (P2P) Lending, and crowdfunding. The following is a list of Fintech Indonesia's startup companies[2]:

1. Payment, in Indonesia the Fintech startup company is mostly dominated by:

a. Payment companies, such as: Veritrans, DoKu, Kartuku, iPay88, Easypay, MCpayment, Padipay, Kinerjapay.com, Truemoney, Faspay, Fasapay, Xendit, Espay, Wallezz, Cashlez, Mimopay, Indopay, Firstpay, IPaymu.com, Ovo, Nicepay, Hellopay, Kesles.

b. Mobile payments companies, such as Sakuku BCA, Dompetku Indosat Ooredoo, My SmartFren Money, Dimo, Mynt, Matchmove

c. Electronic Money: Sepulsa.com, Davestpay.com, GoPay, Indomog, Kudo, Ayopop. 
2. Investment, Indonesia has several startups that provide easy access to investment in the investment sector, such as Bareksa (Mutual Fund Marketplace) and IpotFund (Mutual Fund Supermarket). Xdana.com

3. Lending, this one is engaged in financing

a. Debtors in the form of debt such as UangTeman.com, TemanUsaha.com, Linked.com, BosTunai.com, Mekar.id, Tanihub.com, Taralite.com, Pinjam.co.id, Eragano.com, DrR Rupiah.com

b. Joint-based or mass financing (crowdfunding), such as Wifest.com, Kitabisa.com, Ayopeduli.com and GandengTangan.org. WeCare.id, Indves.com, iGrow.asia.

c. Peer to Peer Lending (P2P) based financing : Koinworks.com, Amartha.com, DanaDidik.com, Crowdo.com, Investree.com.

d. Installments Without Credit Cards: Kredivo.com, ShootYourDream.com, Cicil.co.id

\section{Literatur Review}

\subsection{The Concept Of Productive Waqf}

The waqf system in Islam is not a system adopted from a system that has existed before; it is a pure system taught in the Qur'an and al Sunnah.[3] Waqf is not only limited to places of worship, but includes social, educational, economic and welfare fields. Waqf has proven to be an instrument of social security, not only to help basic needs but also play a part in empowering more productively in all sectors such as education, social, economic, and cultural. Aside from assets that do not move from waqf, there are also more cash waqf productive use. Cash waqf which is very potential but not popular causes waqf role has not been optimal to be an instrument of public welfare. Indonesia, with the largest number of Muslims in the world, should be the basis for optimizing waqf.[4] Cash waqf provides many great opportunities, it is not only allocated for infrastructure development but also provides opportunities for the development of others; therefore, e-waqf is needed to support the economy for the welfare needs of the community.

To make the benefits of waqf be more efficient and well-controlled, it need to utilize information technology advancements or $e$-waqf. There are several advantages to this $e$-waqf system, among others:

1. Cash waqf is more flexible and becomes a stimulant for endowment assets that are not moving, to be more productive.

2. Application-based waqf transactions are application forms that can be owned by smartphone users in the world.

3. There is a mapping of waqf wealth distribution and it is still not accumulated in the local area. It also aims to distribute wealth and eliminate inequality.

4. Waqf wealth transparency, so that it can increase trust muwaqif .

Cash waqf can be used as a source of capital for the business, especially for companies whose main purpose is to empower community businesses in general, Micro Small Medium Enterprises (MSMEs) and startup companies. However, the term cash waqf is not so familiar in Indonesian society. This can be seen from the understanding of Indonesian who view waqf as limited to giving in the form of immovable property, such as land and buildings intended for places of worship, graves, Islamic boarding schools, orphanages and education. [5] The use of waqf objects still revolves around physical things so that it does not have a significant 
economic impact on the welfare of the community. Many properties of waqf in Indonesian society have not been able to overcome the problem of poverty.

Cash waqf opens up unique opportunities to create investments to provide religious services, educational services, and social services. Savings of the rich can be utilized by exchanging them with Cash Waqf Certificate. The results of the development of waqf obtained from the certificate can be utilized for purposes as diverse as the goals of waqf itself. Another use of the Cash Waqf Certificate is that it can change the old habit of making waqf opportunities as if it were only for the rich.

The Indonesian Council of Ulama (MUI) has issued its Fatwa regarding cash waqf on May 11, 2002, which states that:

1. Cash Waqf (Waqf al-Nuqud) is a waqf made by a person, group of people, institutions or legal entities in the form of money.

2. Securities are included in the notion of money.

3. The law of cash waqf is jawaz (allowed)

4. Cash waqf can only be distributed and used for things that are permitted sharply

The principal value of cash waqf is that its sustainability must be guaranteed, may not be sold, granted and/or bequeathed.

\subsection{Waqf Model for Capital}

Waqf or endowments that can be used for empowerment and / or sources of capital for startup companies are money and immovable assets or assets that can be used as factors of production. Assets (money and non-money) endowments are handed over to institutions or individuals or organizations (nadzir) to be managed to provide benefits to the community and these assets are maintained in a sustainable manner. Waqf model as a capital solution is described as follows:

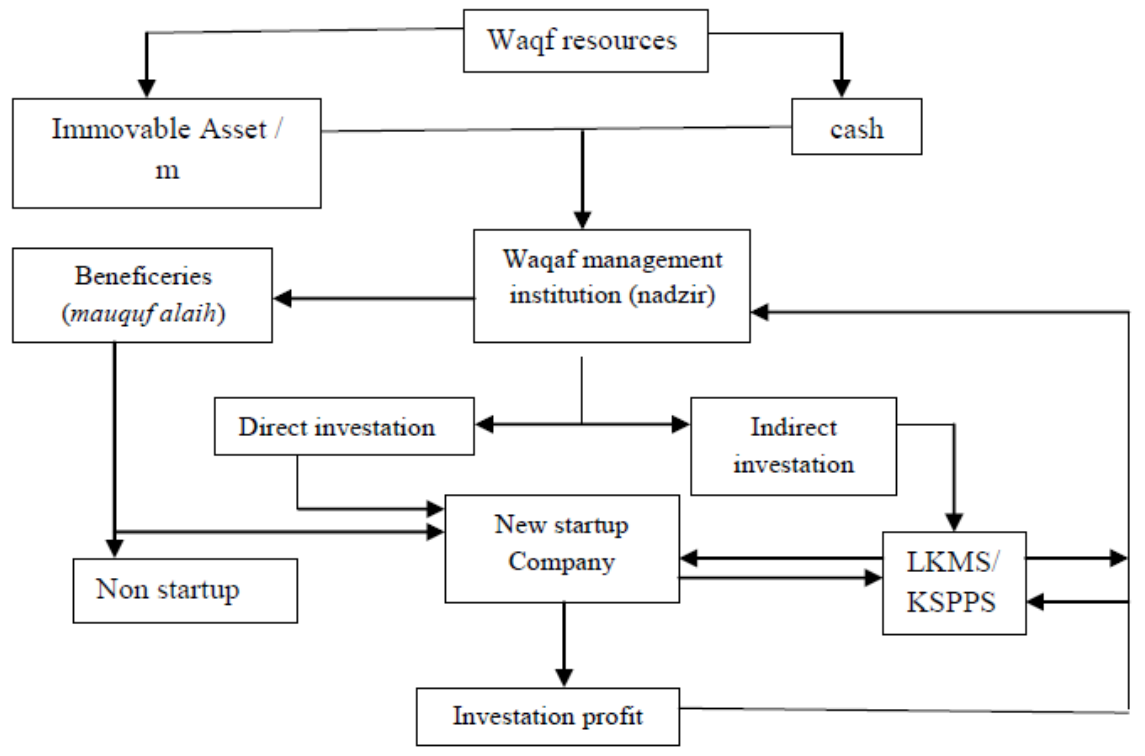

Fig. 1. waqf model as a capital solution 
In managing the assets of immovable waqfs like land, building, machinery, and other production factors, nadzir can be directly included directly in startup companies. This production factor can directly be used by startup companies in production as an investment. Waqf assets that are used as inclusion must be valued in rupiah, because they will be used to calculate the right of return obtained from startup business.[6]

Cash waqf may not be directly coming from nadzir to startup companies. It must cooperate with financial institutions or investment managers. Even, cash waqf may only be represented through Sharia Financial Institutions that Receive Cash waqf Recipients (LKS PWU) which are authorized and appointed by the Minister of Religious Affairs of the Republic of Indonesia. This is regulated in Act Number 41 of 2004 concerning Waqf, in Article 23; "Wakif can endow a movable object in the form of money through LKS designated by the Minister as LKS of Cash waqf Recipient (LKS-PWU)".[7] These PWU LKS are Sharia Commercial Banks (BUS), Sharia Business Units (UUS), Sharia MIkro Financial Institutions (LKMS), Savings and Loans and Sharia Financing Cooperatives (KSPPS), Savings and Loans Units, and Sharia Financing (USPPS). KSPPS is better known in the community Baitul Maal Wat Tamwil (BMT).

Cash waqf in capital startup management companies in collaboration with KSPPS or USPPS which has become nadzir with two models. The first model, cash waqf is used as capital participation in startup companies or used as KSPPS or USPPS capital which will be distributed as financing to startup companies. Meanwhile, the second model, cash waqf is placed in KSPPS or USPPS with the muqayadah mudharabah agreement. Mudharabah muaqayadah agreement is a mudharabah agreement that provides certain conditions to the fund manager (mudharib) in channeling its investment as determined by the owner of the fund (shahibul maal). In this case, the main requirements should only be distributed to startups which have been appointed by Shahibul Maal.

The cash waqf that becomes an investment (capital) in the startup company business must be maintained and if the results are obtained, the results are shared between startups with KSPPS or USPPS, then divided by nadzir based on the ratio or ratio that has been agreed upon.

\subsection{Sharia Financial Technology (SFT) Model As a Capital Integrator for Waqf-Based Startup Companies.}

Fintech has replaced the banking function in mediating between those who offer funds (savers) and requests for funds (credit) more efficiently without time limits and penetrates regional boundaries that had been difficult for banks to reach. This system is able to integrate and bring together parties involved in financial services without having to meet face to face.

Fintech has been widely adopted by the conventional financial industry as well as Islamic finance. This digitization has also begun to be adopted by philanthropic activities in crowdfunding and financing, this fintech system has also begun to be adopted by the activity of representation into e-waqf.

Whereas in the case of audits, the role of electronic audit (Electronic Data Process or EDP) will be increasingly important in digitizing business processes. As a result, the OJK requires the implementation of fintech to provide an audit trail for all its activities in an information technology-based electronic system. Audit track records are useful for supervision, law enforcement, dispute resolution, verification, testing and other examinations.[8] 
The Fintech application in membership as a startup capital source can be seen in the following figure.

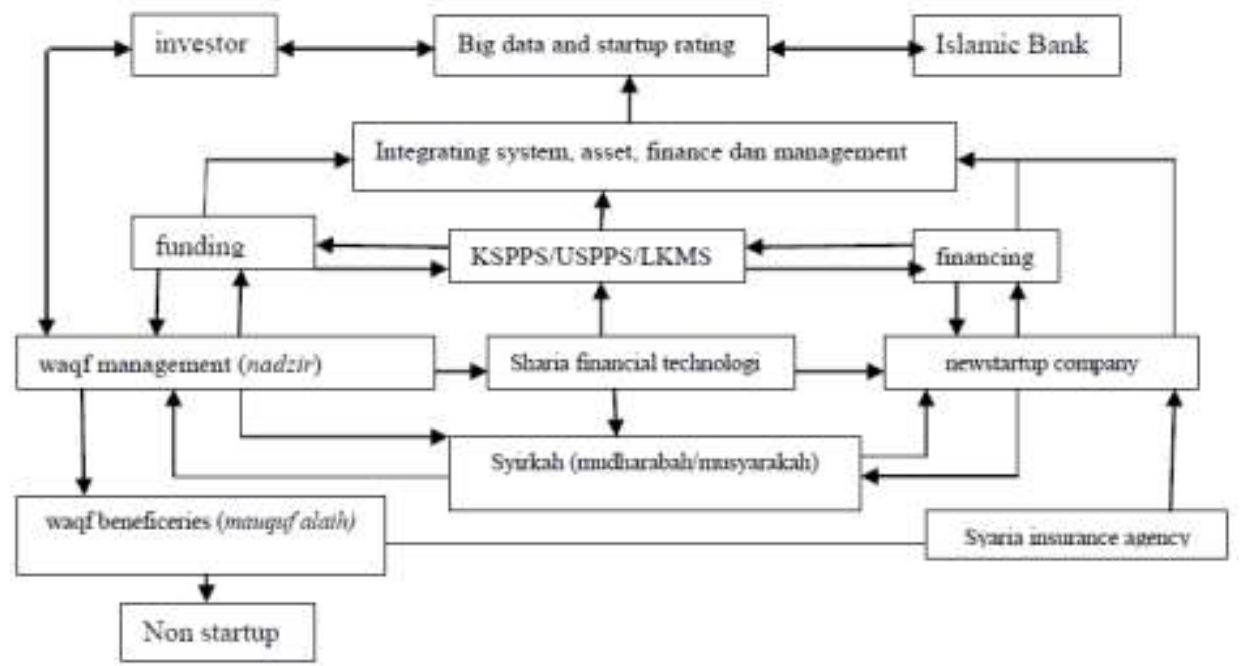

Figure 2. Fintech application in membership as a startup capital source

The figure above shows that the fintech sharia is applied in the waqf system has been able to integrate nadzir with Receiver Waqf Islamic Financial Institutions Money (LKSPWU), funding, financing, mauquf alaih, investors startup company, Islamic Financing Guarantee Institution (LPPI) and Bank Islam. The financial integration model with FinTech can be used to solve capital problems at startup companies. In this system, the institution for managing cash waqf (nadzir) plays a dual function, namely as funding and financiers (equity participation). Sharia Microfinance Institutions (LKMS) in this case are played by KSPPS or USPPS.

Collecting cash waqf can be conducted by nadzir using Fintech. Through this system, nadzir can collect cash waqf ranging from a small value to a very large amount even though it has been very uneconomic to be very economical because crowdfunding costs are very cheap or even free. This is not possible without the Fintech system. Producing cash waqf with Fintech can be done either directly or indirectly.

Direct distribution of cash waqf to startup companies with investment can be done through mudharabah and musyarakah agreements. In cooperation through the mudharabah contract, the startup company acts as a party that has business expertise (mudharib). While nadzir acts as the provider of all capital (shahibul maal) needed by startup entrepreneurs. Through a musyarakah agreement, nadzir and startup companies both deposit capital in nominal terms according to ability or based on the agreement of the parties in the musyarakah. Distribution of waqf as a startup company capital does not require rigid conditions such as banking requirements. The main consideration in this capital is a benefit for startup companies and the public interest in general, commitment and business plan that is SMART (Specific, Measurable, Accurate, Reliable, and Timely). This is because the main purpose of this system is to provide solutions to the difficulty faced by startup capital in the startup company. access capital to formal financial institutions that are profit oriented.

The profit sharing will be given by startup company to the institution, either directly or indirectly based on the value added or profits derived. In the results of direct distribution, the 
profit sharing occurs only at one level, namely the profit sharing between startup companies and nadzir. Whereas, profit sharing in the distribution system is indirectly carried out with two levels. The first level is the profit sharing between startup companies with KSPPS or USPPS. For the second year the results are revenue sharing from yields received by KSPPS and USPPS and then shared again with nadzir.

Revenue received nadzir will be used for operational expenses and the rest will be distributed to beneficiaries of waqf (mauquf alaih). This cycle continues to rotate so that the function of waqf in empowering the community and creating public benefit is getting optimum from time to time.

\section{Conclusion}

Cash waqf in Indonesia have enormous potential and are easily managed compared to waqf of immovable assets. In this section we have described the benefits of cash waqf which is easier to use as a source of capital for both companies that are already stable and new startup companies. This waqf model as startup capital really helps capital for Muslim entrepreneurs to utilize waqf funds collected for business continuity. As a result, it is expected that waqf will contribute in increasing economic growth in Indonesia by contributing through community SMEs so as to create new jobs and realize the development of new economics and business based on Islamic values. However, other scientific studies are needed to develop waqf fintech and digital waqf so that management and distribution is guaranteed. Besides, in terms of practice, the role of Islamic tertiary institutions is needed to contribute to maximizing the management of economic waqf potentials to reduce the list of job seekers among scholars. Thus, the development of waqf will be the empowerment of the people's economic sector throughout the region.

\section{References}

[1] E. Santi, "Pengawasan Otoritas Jasa Keuangan terhadap Financial Technology (peraturan otoritas jasa keuangan nomor 77/pojk.01/2016," Diponegoro Law J., vol. 6, no. 3, 2017.

[2] rubi, "Financial Technologi," Finansialku.com, 2019. .

[3] S. H. Mansur, al-Waqf wa Dauruhu fi al-Mujtama' al-Islami al-Mu'asir. Beirut: Muasssah alRisalah, 2004.

[4] E. N. Sifa, "E-Waqf as an Alternative Solution for Infrastructure Development Based on Crowdfunding," Muhammadiyah Univ. Metro First Int. Conf. Law, Econ. Educ., 2016.

[5] Direktorat Pemberdayaan Wakaf dan Direktorat Jenderal Bimbingan Masyarakat Islam, "Strategi Pengembangan Wakaf Uang di Indonesia," in Strategi Pengembangan Wakaf Uang di Indonesia, 2009, p. 8.

[6] M. Nafiq, "Fintech Waqaf: Solusi Permodalan perusahaan Startup Wirausaha Muda, Jurnal Studi Pemuda," Fintech Waqaf, no. 7, 2018.

[7] U. Pemerintah, "Undang-Undang Republik Indonesia no. 41 Tahun 2014 tentang Wakaf.," in Undang-Undang Republik Indonesia no. 41 Tahun 2014 tentang Wakaf., 2014.

[8] A. Yulianti, "Dibalik Fintech Syariah,” Republika.co.id, 2019. . 